\title{
Left atrial rupture due to blunt thoracic trauma
}

\author{
İlker Akar, M.D., ${ }^{1}$ İlker İnce, M.D., ${ }^{1}$ Cemal Aslan, M.D., ${ }^{1}$ Mehmet Çeber, M.D., ${ }^{1}$ İlker Kaya, M.D. ${ }^{2}$
}

${ }^{1}$ Department of Cardiovascular Surgery, Gaziosmanpasa University Faculty of Medicine, Tokat

${ }^{2}$ Department of Cardiovascular Surgery, Tokat State Hospital, Tokat

\begin{abstract}
Blunt traumatic cardiac rupture is rare and associated with high mortality. The most popular theory of cardiac rupture after blunt thoracic trauma is rapid deceleration with disruption of the atria from their connections to the vena cava and pulmonary veins. In cases with both massive hemothorax and hemopericardium, injury can usually originate from the heart and/or major vessels. Surgical approach through the median sternotomy can provide convenience to repair the defect. In this article, successful treatment with median sternotomy of a 33-year-old male case with a rupture of the left atrium after blunt thoracic trauma was reported.
\end{abstract}

Key words: Blunt thoracic trauma; left atrium; rupture.

\section{INTRODUCTION}

The incidence of cardiac rupture after blunt thoracic trauma ranges from approximately $0.16-2 \%$. Left atrial rupture, among cardiac injuries, is also rare and a catastrophic event associated with high mortality rates. Several mechanisms of blunt traumatic cardiac rupture have been described. The most popular theory of cardiac rupture after blunt thoracic trauma is rapid deceleration with resultant disruption of the atria from their connections to the vena cava and pulmonary

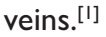

This study reported the case of 33-year-old man with a rupture of the left atrium-right superior pulmonary vein connection after blunt thoracic trauma.

\section{CASE REPORT}

A 33-year-old male was brought to the emergency service after a fall from height. He was awake, alert, and oriented to person, place, and time. He was only suffering from back-

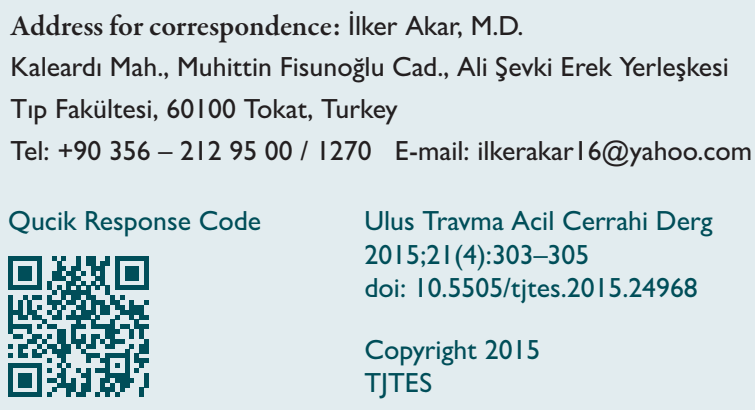

ache. On physical examination, there were small bruises on his chest. Cardiovascular evaluation revealed only distantsounding heart sounds, without hypotension or distended jugular veins. His respiratory rate was 20 breaths per minute, pulse rate was 120 beats per minute, and blood pressure was $100 / 50 \mathrm{mmHg}$. Chest $\mathrm{X}$-ray radiography showed an enlarged cardiac silhouette with mediastinal widening and right pleural effusion. In thoracoabdominal computed angiography tomography (CAT), the hemopericardium and right hemothorax were seen (Fig. I). Major vessels of the mediastinum were normal. In echocardiography, there was markedly pericardial effusion. The patient was taken to the operating room with a pre-diagnosis of cardiac rupture. After midline sternotomy and pericardial incision, $400 \mathrm{ml}$ fibrin blood gushed out. On the examination of the heart, left atrial rupture was detected at the pulmonary vein-atrial junction (Fig. 2). Under partial cardiopulmonary bypass, the defect was sutured with a pledgeted 4-0 polypropylene suture. After opening the right pleura, approximately $1200 \mathrm{ml}$ blood was aspirated. There was no bleeding source at the right hemithorax. After weaning from the cardiopulmonary bypass, transeusophageal echocardiography was performed and no defect was seen at interatrial and interventricular septum. The postoperative period was uneventful, and the patient was discharged on the postoperative six day without any complications.

\section{DISCUSSION}

The incidence of cardiac injury after blunt chest trauma varies from $8 \%$ to $86 \%$ in reported series. ${ }^{[2-4]}$ Cardiac rupture was detected in $96.9 \%$ of the fatalities caused by a blunt mechanism among 160 trauma autopsies with cardiac injury. ${ }^{[4]}$ The 


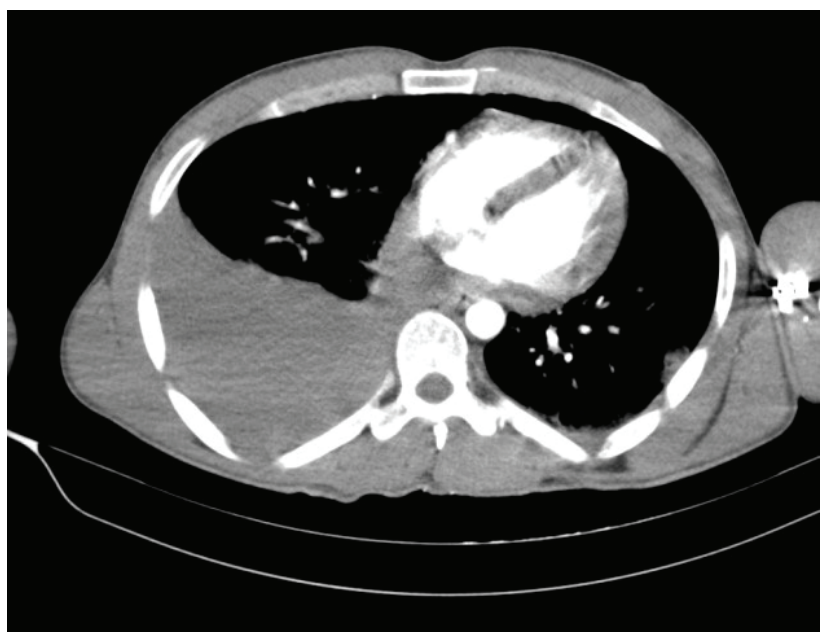

Figure 1. Computed tomography angiography image of hemopericardium and hemothorax.

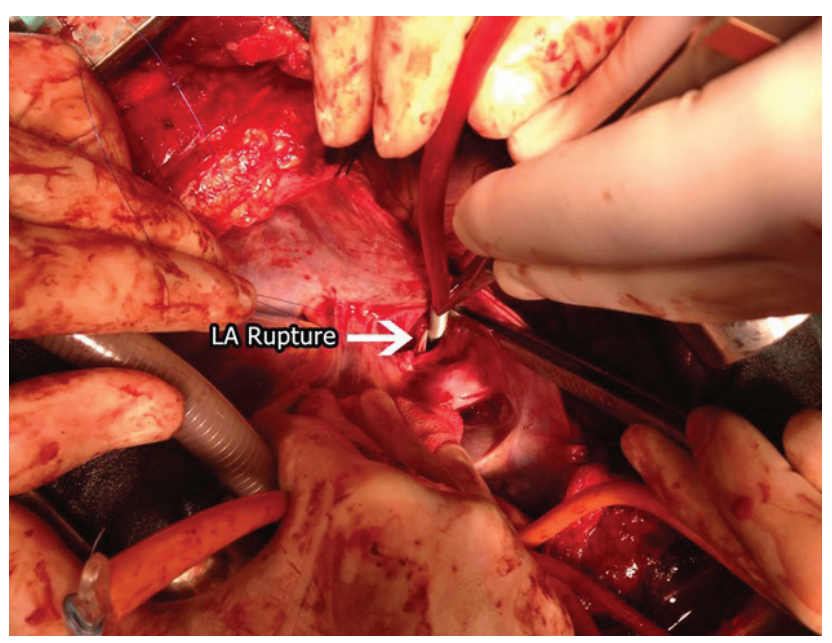

Figure 2. Intraoperative scene of the left atrial rupture.

spectrum of potential injuries to the heart after blunt chest trauma is wide, including myocardial contusion, free wall or septal rupture, valvular disruptions, and injury to the great vessels. $^{[4,5]}$. Chamber rupture has high mortality, and most patients cannot reach to the emergency room. ${ }^{[6]}$ The National Trauma Data Bank reports that chamber rupture represents $0.041 \%$ of all trauma cases and has $89.2 \%$ mortality rate. ${ }^{[7]}$ Cardiac rupture is predominantly observed in the relatively weaker right side of the heart than in the left side. In a report, the anatomic distribution of chamber injuries were: right atrium, twenty-one patients (50\%); right ventricle, seven patients ( $17 \%)$; left atrium, ten patients $(24 \%)$ and left ventricle, four patients (9\%). The underlying mechanisms of blunt cardiac rupture were as follows: (i) direct precordial impact, (ii) compression of the heart between the sternum and vertebral column, (iii) rapidly increased hydrostatic venous pressure transferred from the abdomen or lower extremities to the heart, (iv) acceleration/ deceleration force, and (v) direct penetration by the sternum or rib fractures. ${ }^{[6]} \mathrm{A}$ rapidly increased hydrostatic pressure usually affects the right atrium, and deceleration force usually causes a disruption of the vena cava-atrial and pulmonary vein-atrial junctions. ${ }^{[8]}$ In our case, there was a self limited rupture with hematoma at the junction of the right superior pulmonary vein-left atrium due to the accidental fall which caused to deceleration trauma.

The clinical situation in blunt cardiac injuries varies from simple myocardial contusion without symptoms to cardiogenic shock because of cardiac tamponade. In asymptomatic patients, elevated cardiac enzymes can be seen. In chest trauma patients presenting with no clinical signs, the diagnosis of blunt cardiac injury is often difficult and requires several diagnostic tests. ${ }^{[9]}$ If there is mediastinal widening with left or right hemothorax in chest graphy, cardiac injury should be considered and further investigations as echocardiography and computed tomography have to be performed. In our case, there was no symptom suggesting cardiac injury. In chest X-ray graphy, the right hemothorax and mediastinal widening were detected. In echocardiography, there was markedly pericardial effusion. The right hemothorax and hemopericardium were detected at CTA. The mediastinal main vessels were normal. The patient was taken to the operating room with the diagnosis of cardiac rupture.

After blunt thoracic injuries, at the present of massive hemothorax, most non-cardiac surgeons tend to do thoracotomy rather than median sternotomy, but thoracotomy only provides limited surgical exposure of the heart and ascending aorta. Leavitt et al. have found an equal incidence of the initial types of incisions in their review, with $48 \%$ median sternotomies and $45 \%$ left thoracotomies. ${ }^{[6]}$ However, median sternotomy provides good exposure of the entire heart and the ascending aorta, and it is suitable for a cardiopulmonary bypass and extracorporeal life support. Yu-Yun Non et al. have prefered sternotomy upon thoracotomy as the initial approach for suspected blunt traumatic cardiac rupture in their series of patients $(8 / 11,72.7 \%)$. The additional two have been shifted from initial thoracotomy to sternotomy to facilitate cardiac repair $^{[l]}$ In our patient, median sternotomy was preferred instead of thoracotomy. We repaired the defect at the junction of the left atrium and right superior pulmonary vein under partial cardiopulmonary bypass due to hemodynamic instability.

Cardiac rupture is an infrequent, but frequently a fatal sequelae of blunt thoracic trauma. When no external wound is visible and vital signs are relatively stable, the possibility of cardiac rupture after blunt trauma is easily overlooked. If there is any suspicion of cardiac rupture, expeditious diagnostic protocols and appropriate surgical management are essential to get a better outcome.

\section{Conflict of interest: None declared.}

\section{REFERENCES}

1. Nan YY, Lu MS, Liu KS, Huang YK, Tsai FC, Chu JJ, et al. Blunt traumatic cardiac rupture: therapeutic options and outcomes. Injury 2009;40:938-45. CrossRef 
2. Schultz JM, Trunkey DD. Blunt cardiac injury. Crit Care Clin 2004;20:57-70. CrossRef

3. El-Chami MF, Nicholson W, Helmy T. Blunt cardiac trauma. J Emerg Med 2008;35:127-33. CrossRef

4. Fedakar R, Türkmen N, Durak D, Gündoğmuş UN. Fatal traumatic heart wounds: review of 160 autopsy cases. Isr Med Assoc J 2005;7:498-501.

5. Thors A, Guarneri R, Costantini EN, Richmond GJ. Atrial septal rupture, flail tricuspid valve, and complete heart block due to nonpenetrating chest trauma. Ann Thorac Surg 2007;83:2207-10. CrossRef
6. Leavitt BJ, Meyer JA, Morton JR, Clark DE, Herbert WE, Hiebert CA. Survival following nonpenetrating traumatic rupture of cardiac chambers. Ann Thorac Surg 1987;44:532-5. CrossRef

7. Teixeira PG, Inaba K, Oncel D, DuBose J, Chan L, Rhee P, et al. Blunt cardiac rupture: a 5-year NTDB analysis. J Trauma 2009;67:788-91.

8. Martin TD, Flynn TC, Rowlands BJ, Ward RE, Fischer RP. Blunt cardiac rupture. J Trauma 1984;24:287-90. CrossRef

9. Sybrandy KC, Cramer MJ, Burgersdijk C. Diagnosing cardiac contusion: old wisdom and new insights. Heart 2003;89:485-9. CrossRef

\section{OLGU SUNUMU - ÖZET}

\section{Künt toraks travmasına bağlı sol atriyal yırtık}

\section{Dr. İlker Akar, ${ }^{1}$ Dr. İlker İnce, ${ }^{1}$ Dr. Cemal Aslan, ${ }^{1}$ Dr. Mehmet Çeber, ${ }^{1}$ Dr. İlker Kaya ${ }^{2}$}

${ }^{1}$ Gaziosmanpaşa Üniversitesi Tıp Fakültesi, Kalp ve Damar Cerrahisi Anabilim Dalı, Tokat

${ }^{2}$ Tokat Devlet Hastanesi, Kalp ve Damar Cerrahisi Kliniği, Tokat

Künt travmatik kardiyak yaralanma nadir olmakla birlikte yüksek mortalite ile ilişkilidir. Künt toraks travması sonrası kalp yırtı̆ının oluşmasındaki en geçerli teori; hızlı deselerasyona bağlı atriumların vena kava ve pulmoner venler ile birleşme yerlerinden oluşacak yırtılmadır. Hemotoraks ve hemoperikardiyumun birlikte olduğu olgularda yaralanma genellikle kalp ve/veya büyük damarlardan kaynaklanabileceğinden median sternotomi ile olan yaklaşım yaralanmanın tamiri için kolaylık sağlar. Bu yazıda, 33 yaşında bir erkek olguda künt toraks travması sonrası oluşan sol atriyal yırtığın mediyan sternotomi ile başarılı bir şekilde tedavisi sunuldu.

Anahtar sözcükler: Künt toraks travması; sol atriyum; yırtık.

Ulus Travma Acil Cerrahi Derg 20I5;2I(4):303-305 doi: 10.5505/tjtes.20I5.24968 